\title{
Do Consumers Trust Mobile Service Advertising?
}

\author{
Robert Davis \\ Unitec Institute of Technology \\ E-Mail: rdavis@unitec.ac.nz \\ Laszlo Sajtos \\ University of Auckland \\ E-Mail: 1.sajtos@auckland.ac.nz \\ Ahsan Ali Chaudhri \\ Southern Cross University \\ E-Mail: a.chaudhri@scu.edu.au
}

\begin{abstract}
Mobile services have rapidly become an important way for consumers to communicate, encounter services and exchange information. Marketers are increasingly using this channel for brand related advertising communications. However they have found that consumers are reluctant to try and adopt new mobile services and/or other products/services in response to advertising, unless the consumer has established trust. This research investigates whether consumers trust advertising communications sent by marketers through mobile service channels. To answer this question we measure trust-related factors that are antecedent to the consumer's overall trust in these advertising communications and their relationship to the consumer's willingness to buy the advertised brand. Our model was tested using structural equation modeling. The results indicate that the reputation of the vendor, disposition to trust, structural assurance, perceived ease of use, third party assurance and perceived privacy have the highest impact on consumer trust and willingness to buy.
\end{abstract}

Keywords: Consumer, Trust, Mobile, SEM, Service, Advertising 


\section{INTRODUCTION}

The objective of this research is to confirm whether consumers trust advertising communications sent by marketers through mobile service channels (Wei, Xiaoming, and Pan, 2010; Taylor and Lee, 2008; Merisavo et al. 2007; Leppäniemi and Karjaluoto, 2005). We measure trust-related factors that are antecedent to a consumers overall trust in these advertising communications and its relationship to their willingness to transact with the advertised brand (Tsang, Ho, and Liang, 2007). First, we build a conceptual model that identifies relevant antecedents to consumer trust. Next, we present our methodology and analyze our data using structural equation modeling to test the overall model. Finally, we conclude with a discussion of the implications for managers.

This research objective is important because, in service environments, the mobile channel has rapidly become an important way consumer and businesses communicate with each other (Shankar, Urban, and Sultan 2002; Okazaki 2009), encounter services or exchange information: anywhere, anytime, anyplace (Tarasewich, Nickerson, and Warkentin 2002; Nysveen, Pedersen, Thorbjørnsen, and Berthon, 2005). For consumers, these service markets provide a range of offerings for banking, reservations, finding locations, paying for parking and downloading content (e.g., games or music) for their mobile phone (Reyck and Degraeve, 2003; Okazaki, 2005).

This potential has not gone unnoticed by marketers, who have started to explore the effectiveness of the channel for related communications (Kerckhove, 2002; Nysveen, Pedersen, and Thorbjørnsen 2005; Ferris 2007). Companies like Google have integrated the mobile channel into their array of service offerings to make the experience of interacting with their brand convenient, personal and relational (Drosses, Giaglis, Lakeakos, Kokkinaki, and Stavraki, 2007; Wang, 2007). For Google, the mobile service channel increases the potential for truly customized, one-to-one targeted communications (Gao, Sultan, and Rohm 2010). Also, the underlying technology (Jun, and Lee 2007) creates opportunities for delivering information while building relationships with consumers through marketing communications (Balasubramanian, Peterson, and Jarvenpaa 2002; Nysveen et al. 2005).

Despite the benefits, research indicates that many consumers are only willing to use a limited number of services (Anckar and D'Incau, 2002; Jarvenpaa, Lang, Takeda, and Tuunainen, 2003). This could be because the enhanced potential for personalization and customization means that consumers place greater importance on their level of trust in the marketer. For consumers to engage in this channel they must 
trust the value-exchange process (Quelch, and Klein, 1996; Siau, and Shen, 2003), but some might perceive the mobile channel to be riskier than brick-and-mortar or even web-based service environments (Soroa-Koury and Yang, 2009; Komulainen, Mainela, Ta“htinen, and Ulkuniemi, 2007; Siau and Shen, 2003; Gerstheimer and Lupp, 2004).

Other factors may erode consumer trust, contributing to their reluctance to use the mobile service channel to transact with the vendor (Siau and Shen, 2003; Anckar and D'Incau, 2002). First, like web-based commerce, there is a lack of face-to-face interaction, meaning that the consumer cannot physically see and judge the legitimacy of the vendor (Chen and Dhillon, 2003). The major threat to the consumer in this case is that the vendor can easily behave opportunistically (Watson, Pitt, Berthon, and Zinkhan, 2002). Second, consumers may perceive a threat to their privacy, as the information that the consumer passes on to the vendor may be used in an unethical way by the vendor or unauthorized parties (Culnan and Armstrong, 1999; Gefen, 2000). For example, mobile technology enables the vendors to track a customer's geographic location without consent (Clarke, 2001). Also, the mobile network is more vulnerable to attacks than a standard physical network or even a web-based network. The mobile channel makes people more wary of risks regardless of their technical knowledge of information security. This awareness is polarized by their experiences on the Internet and the media coverage about hackers stealing sensitive information, as well as losses incurred from unauthorized access from hackers (Chellappa and Pavlou, 2002). Therefore, that the technology itself can greatly affect trust (McKnight and Chervany, 2002). Fourth, while, the mobile service channel has given rise to many services, they are not standardized. For instance, sometimes there is incompatibility in mobile payment systems across different networks, and it requires three or more parties (mobile operator, merchant and financial institution) to enable the transaction (Ancarani and Shankar, 2003). The consumer may not know who is responsible if the transaction fails. Finally, many mobile services are priced at a premium level, so the consumer will be more concerned about whether the vendor will deliver on their expensive promises.

We posit that, for such markets and service offerings to grow, marketers should consider consumer trust in these services and the way in which the services are communicated (Davis and Sajtos, 2008). Little research has been conducted to empirically measure consumer trust in mobile service channels. Therefore, consistent with our objective, we seek to understand what conditions build consumer trust and thus transactions with the advertised brand. We pose two research questions: First, 
what perceived factors affect consumer trust in the mobile vendor? And, second, how do these factors influence a consumer's perceived willingness to use the mobile service to perform a transaction?

\section{TRUST ANTECEDENTS}

Trust is a key factor in attracting and retaining customers and influence consumer behavior, and it has been researched in a variety of ways. Trust-related research in marketing has focused on the buyer-seller relationship in both industrial and consumer markets (Morgan and Hunt, 1994; Anderson and Narus, 1990). Information technology and systems researchers, particularly in the e-commerce field, have focused their attention on information security and privacy, which affects trust (Shankar et al., 2002). In organizational research, the role of trust related to achieving organizational goals (Mayer, Davis, and Schoorman, 1995) and increasing performance has been investigated (Zaheer, McEvily, and Perrone, 1998). In psychology, the individual's personality traits have been investigated, that is, what makes a person trust (or not trust) another one (Rotter, 1971; Doney and Cannon, 1997) (see Appendix 1).

Based on an analysis of this literature we define trust by integrating four widely accepted dimensions of trust: institutional, knowledge-based, dispositional and calculative (refer Figure 1.).

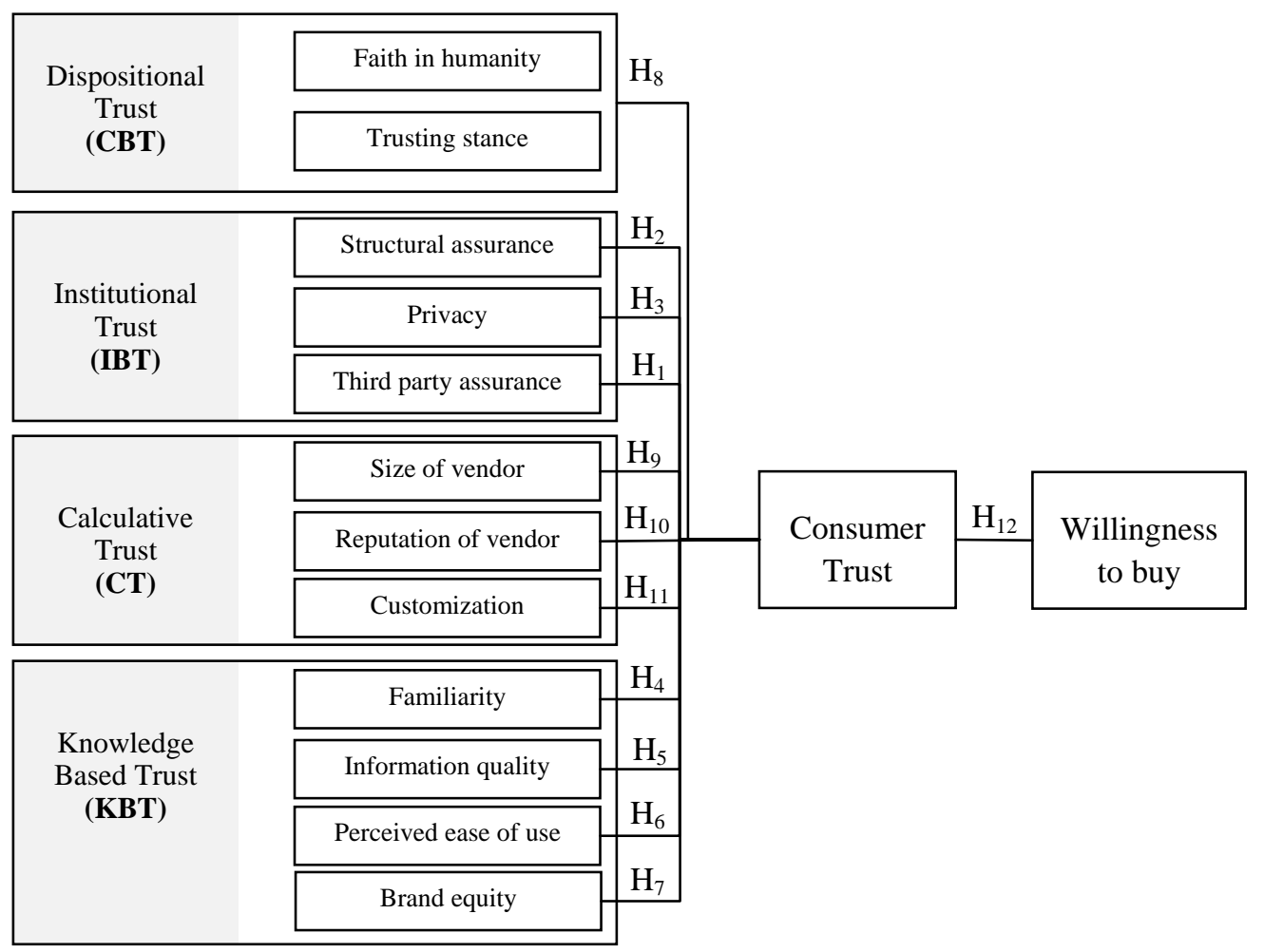

Figure 1 Conceptual Model and Hypotheses 


\section{Institutional trust (H1 to H3)}

In this context, institutional trust arises from a consumer's trust in the technology of the service channel, or "the subjective probability by which an organization believes that the underlying technology infrastructure and control mechanisms are capable of facilitating inter-organizational transactions according to its confident expectations" (Ratnasingham and Pavlou 2003). Just as with the online context there are three main concepts related to technology (Kimery and McCord, 2002): 1) structural assurance (McKnight and Chervany, 2002; McKnight, Cummings, and Chervany, 1998), 2) perceived privacy and 3) third party assurance (Kimery and McCord, 2002; Pavlou, 2001). Structural assurance generally ensures the safety and security of the customer (Zucker, 1986) including safety measures like encryption, authentication, verification and guarantees. Since the mobile service channel is relatively new, customers may perceive the structural assurance as generally poor compared to physical networks and the Internet. Perceived privacy is defined as "the subjective probability with which consumers believe that the collection and subsequent access, use, and disclosure of their private information by web retailers is consistent with their expectations" (Pavlou, 2001). Third party assurance refers to third party companies that act as assurors, which confirm to consumers that a particular retailer complies with the standards laid down by the assuror (Kimery and McCord, 2002). For example, in an online environment, retailers can make consumers aware that the firm's practices are assured by third party sites by showing the third party seal on their website. However, little has been done by third party sites verifying whether the mobile service vendors are reliable.

\section{Knowledge-Based Trust (H4 to H7)}

Knowledge-based trust arises from the consumer's trust of information flowing between the vendor and the consumer. Based on the information accumulated from previous interactions, the consumer forms positive or negative perceptions of the vendor, which influences trust. There are four ways to gain knowledge about the vendor: 1) familiarity with the vendor (Gefen, 2000), 2) the quality of the information communicated to the customer (Koufaris and Hampton-Sosa, 2004), 3) the perceived ease of use of the service (Gefen, Karahanna, and Straub, 2003), and 4) brand equity (Keller, 1993). Familiarity is based on previous experience or understanding in using the mobile interface to perform a transaction with the vendor (Gefen, 2000). Familiarity reduces the complexity involved in the mobile transaction process with the vendor and builds consumer trust (Gefen, 2000). For example, if the consumer is not familiar with 
the way to complete the transaction then he/she will not hold a positive belief that the process will go smoothly and so will not trust the vendor. Information quality refers to how up-to-date, sufficient and accessible the relevant information is (Park and Oung-Gul, 2003). The information should meet the customer's information needs. However, the limited screen size of mobile devices limits the amount of information that can be viewed. This is especially important in case of complex transactions, such as stock trading and banking transactions that require many steps (Anckar and D'Incau, 2002). Information quality can substitute familiarity from past experience. Perceived ease of use (PEOU) is the degree to which the user believes that it does not take much effort to accomplish their tasks (Davis, 1989). According to Gefen, Karahanna and Straub (2003), PEOU effects consumer trust through the consumer's inferences on the simplicity and transparency of the vendor's processes, and thereby the vendor's trustworthiness. Brand equity means that the consumer positively reacts to the marketing promotions of that brand, and will be less sensitive to price changes and more willing to seek out that particular brand over other brands (Keller, 1993). If the brand equity is high, consumer risk is reduced.

\section{Dispositional trust (H8)}

Mayer et al. (1995), Rotter (1971) and Sultan et al. (2002) focused on the impact of personal characteristics on trust, indentifying one's propensity to trust as having a strong influence on ones trust of others. This concept is similar to the construct of disposition to trust (McKnight et al., 1998), which refers to one's willingness to consistently depend on others in different situations. The disposition to trust consists of two concepts: 1) faith in humanity and 2) trusting stance. Faith in humanity refers to the degree to which one believes that others are generally reliable and trustworthy (McKnight et al., 1998). A person with higher faith in humanity would usually be less critical and more tolerant of the mistakes caused by others. Faith in humanity plays a greater role when one cannot draw on other information to indicate trustworthiness (Wrightsman, 1991). Trusting stance refers to one's assumption that a successful outcome will be achieved by dealing with people regardless of whether the person is trustworthy or not (McKnight and Chervany, 2002). Hence a person with a high trusting stance would be more willing to take risks with a higher level of trust in the other party. Trust is defined as the "willingness of a party to be vulnerable to the actions of another party, based on the expectation that the other will perform a particular action important to the trust or, irrespective of the ability to monitor or control that other party" (McKnight et al., 1998; Mayer et al., 1995). For one to be 
vulnerable one has to have something important to lose or gain, so trust assumes reciprocity, that is, the willingness to take risks on both sides of the relationship. The consumer's disposition to trust is usually more important in the early stages of the relationship between company as those early stages require the consumer to trust the vendor without any experience (McKnight et al., 1998). The high level of life experiences of the consumer helps increase his/her level of disposition to trust (Rotter, 1971). Once the consumer has experience in dealing with the vendor, then both parties can begin a continuous trust development (Siau, Sheng, and Nah, 2003) where other factors play a more important role.

\section{Calculative trust (H9 to H11)}

Consumers can make a judgment about the trustworthiness of the vendor by comparing the benefits of the vendor cheating versus their cost of being caught. For example, if the consumer believes that the vendor has more to lose by acting opportunistically than they have to gain, then the vendor will be considered trustworthy (Gefen et al., 2003). There are three ways to make this judgment: through the 1) size of the vendor, 2) reputation of the vendor and 3) the willingness of the vendor to customize the service for the consumer. The size of the vendor refers to the physical size of the vendor itself, and also could mean the number of employees, revenue or market share position of the vendor. These figures could eventually signal the customer that the vendor has a large customer base, which would indicate that other customers have trusted the vendor. Since peer-to-peer communities are very powerful in the mobile services channel, (Ratsimor, Finin, Joshi, and Yesha, 2003) a large company would have more to lose than gain by acting opportunistically, making trust warranted for larger companies. In contrast, consumers perceive smaller vendors as being more opportunistic compared to larger vendors, as smaller companies do not have such a high penalty for cheating compared to the larger companies. Size of the company is closely related to its reputation, which is about how honest and concerned the vendor has been in previous transactions. A good reputation takes considerable time and expense to build, and it can be lost easily (Doney and Cannon, 1997), so companies with a high reputation can lose more than they can gain by acting in an untrustworthy way. Customization is the tendency for businesses to personalize products and services for their customers. Firms that provide customization show that they are willing to give more attention to individual customers (Koufaris and Hampton-Sosa, 2004), which also increases the number of interactions between customer and the company about the specification of the product/service or the service delivery process. Studies have shown that the more communication or interaction there is between the company and the 
customer, the more trust can be established (Anderson and Narus, 1990). Finally, firms that offer customization have to make a large investment in labor, technology and time (Koufaris and Hampton-Sosa, 2004), which is jeopardized if the company behaves opportunistically.

\section{Willingness to buy (H12)}

Based on the discussion above we argue that, in the context of mobile communication, the four major sources of trust are disposition to trust, institutional, calculative and knowledge-based trust. While there are various perspectives, researchers agree that trust enhances the willingness to conduct a 'transaction' (Jarvenpaa et al., 2003; McKnight and Chervany, 2002). Therefore, trust can play a major role in determining and predicting consumer behavior (Mayer et al., 1995), and higher levels of trust equals higher willingness to purchase the item/service.

\section{METHODOLOGY}

To test our proposed model we adapted concepts from previous studies, which are acknowledged next to the items on the questionnaire (Appendix 2). Twelve respondents were chosen from the general public to test the questionnaire, whose feedback led to some modifications in the wording of the questionnaire. A seven point scale was used to measure all antecedents: $1=$ 'strongly disagree' to $7=$ strongly agree. The research was conducted in Auckland, (New Zealand). The respondents were screened before being included $I$ in the study according to 2 criteria: The respondent had to (1) have an enabled SMS and/or MMS mobile phone and (2) have received advertising-related SMS and/or MMS messages. After the screening questions but before the respondents proceeded to the main questionnaire, the respondents were presented a scenario, as follows.

"Imagine that you have registered with Vodafone NZ or Telecom NZ mobile advertising campaign service. Being part of this campaign means that you will receive advertising messages from Vodafone NZ or Telecom NZ or other companies (e.g., Woolworths) in the form of TXT and PXT to your mobile phone on products and services sold by these companies. Some of the advertisements you will receive will be promotional (e.g., offer discounts) while others may enable you to actually purchase the advertised brand using you mobile phones messaging services (e.g., movie tickets)."

Appendix 3 shows the demographic profile of the respondents. The data collection resulted in a final sample size of 301 respondents. From the sample, $55.4 \%$ of 
respondents were females. The majority of the participants are in the 20-49 year age range, had a university degree and were New Zealanders or of European ethnicity. In addition, most had a full-time job and earned between $\$ 30,000$ and $\$ 50,000$ annually. Nokia was the most popular mobile phone brand. On average, respondents sent 2 to 3 text messages daily, and they changed their mobile phones every three years.

\section{ANALYSIS}

In our analysis we employed structural equation modeling (SEM) by using AMOS 6.0. A two-step modeling procedure (Anderson and Gerbing, 1988) was applied, which begins with the purification of the measurement model by testing the individual constructs that underlie the full structural equation model. Despite the established nature of the constructs and due to the new context, we first validated the individual constructs (measurement model) by using confirmatory factor analysis (CFA). Maximum likelihood estimation was used to fit the model, and the concepts were analyzed in subsets to meet the minimum respondent per estimated parameter ratio (Hair, Anderson, Tatham, and Black, 1998). The four groups identified in our literature (Figure 1) served as bases of the subsets. In order to achieve uni-dimensionality, several items were eliminated from the scales. Table 5 provides an overview of the fit indices of the measurement models, which show a reasonably close fit: the normed chi-square value and the root-mean-squared error of approximation (RMSEA) (Browne and Cudeck, 1993) are below and the goodness-of-fit (GOF) measures are above the recommended threshold level (Hair et al., 1998; Byrne, 2001) - except for the GFI measure of subset 2. In summary, we can conclude that the CFA confirmed the existence of the structural model (refer Table 1).

During the first step of the analysis, convergent and discriminant validity were assessed by undertaking a series of confirmatory factor analyses (CFA) for every possible combination of these constructs (Hooley, Greenley, Cadogan, and Fahy, 2005). All differences between the observed Chi-square values were significant at $\mathrm{P}<0.001$, except for the relationship between trusting stance and faith in humanity. These two concepts were combined and labeled as disposition to trust. The results of the final measurement concepts are displayed in Table 2. (The 'Third party assurance' construct only consists of one variable, so there is no reliability or extracted variance calculated). 
Table 1 Measurement Models

\begin{tabular}{cccccccc}
\hline & $\chi \mathbf{2}(\mathbf{d f})$ & $\chi 2 / \mathbf{d f}$ & Significance $(\mathbf{p})$ & GFI & CFI & NNFI & RMSEA \\
\hline Subset 1 & $112.52(71)$ & 1.58 & .001 & 0.95 & 0.98 & 0.98 & 0.044 \\
\hline Subset 2 & $425.38(240)$ & 1.77 & .000 & 0.90 & 0.94 & 0.94 & 0.051 \\
\hline Subset 3 & $65.93(33)$ & 2.00 & .001 & 0.96 & 0.98 & 0.97 & 0.058 \\
\hline Subset 4 & $136.39(84)$ & 1.62 & .000 & 0.94 & 0.97 & 0.96 & 0.046 \\
\hline $\begin{array}{c}\text { Initial structural } \\
\text { model }\end{array}$ & $276.26(118)$ & 2.34 & .000 & 0.89 & 0.86 & 0.84 & 0.067 \\
\hline $\begin{array}{c}\text { Final structural } \\
\text { model }\end{array}$ & $195.63(111)$ & 1.76 & .000 & 0.92 & 0.93 & 0.91 & 0.050 \\
\hline
\end{tabular}

Note: Subset 1 includes third party assurance, structural assurance, perceived privacy and consumer trust; Subset 2 includes familiarity, information quality, perceived ease of use, brand equity and consumer trust; Subset 3 includes disposition to trust and consumer trust; and Subset 4 includes size of vendor, reputation of vendor, customization and consumer trust.

Table 2 Concept Information

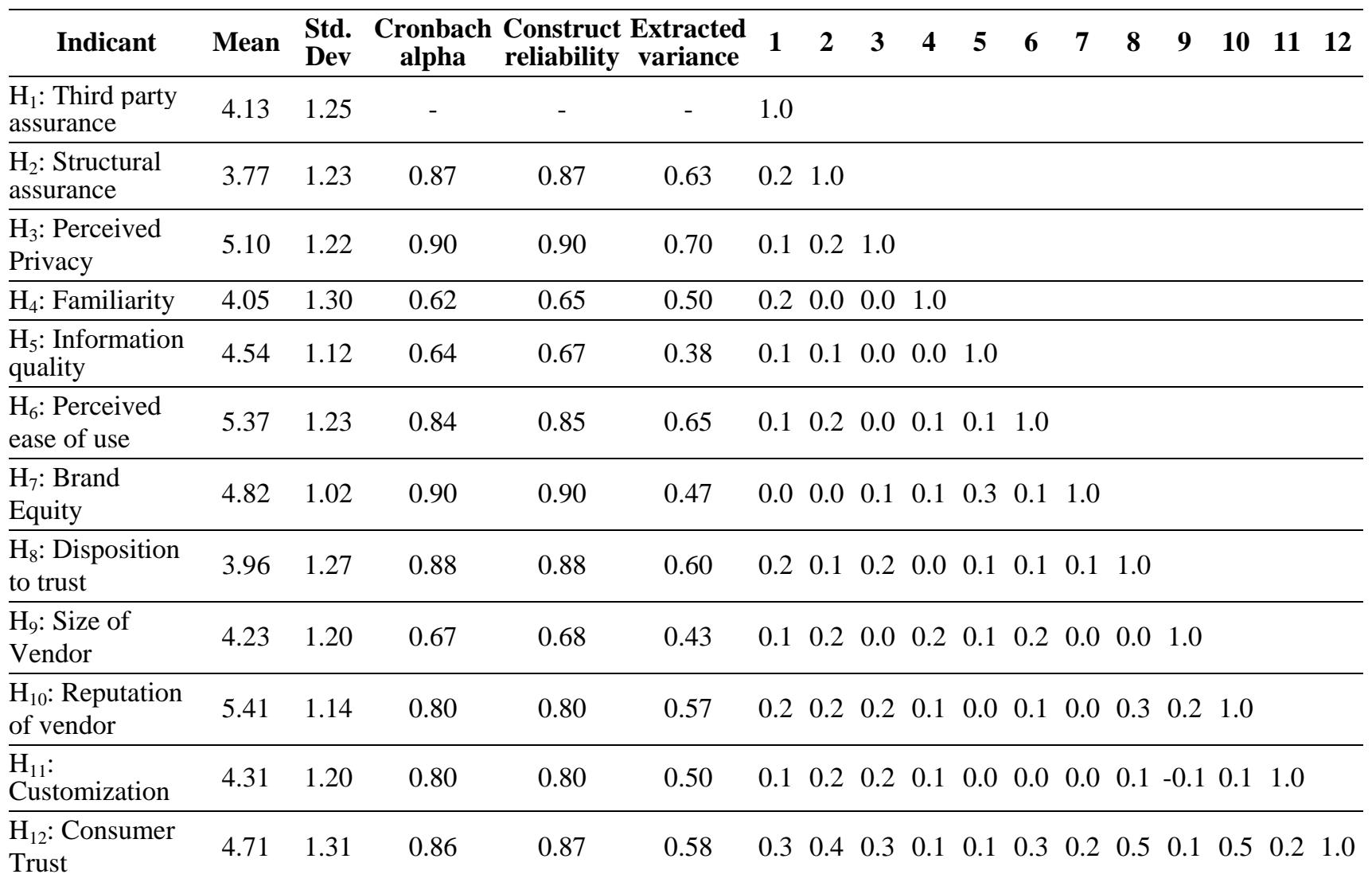


The measurement constructs perfectly meet the minimum threshold level of 0.5 for construct reliability (Hair et al., 1998) and show a great similarity with Cronbach alphas, which are all above the required level of 0.7 (Nunally, 1978) - except Familiarity, Information quality, Size of vendor. With regard to extracted variance there are also three concepts (Information quality, Brand equity, Size of vendor) that are below the minimum threshold level of 0.5 (Hair et al., 1998). The respondents agreed the most with the reputation of the vendor (mean value $=5.41$ ), the perceived ease of use (5.37), the perceived privacy (5.1) and the brand equity (4.82), whereas they disagreed with the structural assurance (3.77), the disposition to trust (3.96) and familiarity. With regard to the relationship between the individual variables, there is a really low level of correlation between the independent (exogenous) variables, which means multiollinearity is not present. All of the correlations are below 0.3 , and most of the highest ones are related to the reputation of the vendor as well as the perceived privacy indicants. However, most of the indicants are highly correlated with consumer trust, especially the reputation of vendor $(r=0.51)$, the disposition to trust $(0.49)$ and the structural assurance (0.43), thus, we presume that these indicants will be the best predictors of consumer trust in the structural model, as well.

As a second step of the two-step modeling approach we propose a base model retained from the first step and a revised model that explores additional relationships between the antecedents of consumer trust. In order to analyze the full structural equation model and to meet the required respondent to estimated parameter ratio we have combined the individual variables of the constructs into composite scales. The advantages of the composite scale are that they are easy to replicate, representative to the construct and, to some extent, they overcome the measurement error inherent in all measured variables (Hair et al., 1998). Due to the application of composite scales, the error variances of the composite scales are to be fixed according to the formula $[(1-\alpha)$ $\times \sigma^{2}$ ], in which $\alpha$ and $\sigma$ represent the composite reliability and the standard deviation of the construct, respectively. The initial model indicates a close fit; the goodness-of-fit (GOF) measures were slightly lower than the minimum threshold level. In line with our proposed exploration of links between antecedents and consumer trust we have refined the model by analyzing the standardized residuals and modification indices (Hair et al., 1998). In accordance with the proposed purpose of our study the final, re-specified measurement model includes seven additional interrelations among the antecedents in addition to the base model. These findings are consistent with the correlation coefficients presented above (See Table 3).

The normed chi-square as well as all GOF measures of the final model show an 
excellent fit (See Table 1). By examining the individual indicants it should be noted that 4 out of 11 antecedents are not related significantly to consumer trust: familiarity, information quality, size of vendor and customization. From the remaining seven exogenous variables, the reputation of the vendor (RV), disposition to trust (DT) and structural assurance (SA) show the strongest relationship with consumer trust (CT), followed by perceived-ease-of-use (PEOU), third party assurance (TPA), perceived privacy $(\mathrm{PP})$ and brand equity $(\mathrm{BE})$.

Table 3 Standardized Path Coefficients

\begin{tabular}{|c|c|c|c|c|c|c|c|}
\hline \multicolumn{8}{|c|}{ Regressions } \\
\hline & & & $\begin{array}{c}\text { Standardized } \\
\text { parameter estimate }\end{array}$ & Estimate & Standard error & t value & Significance \\
\hline CT & $<--$ & TPA & 0.163 & 0.150 & 0.043 & 3.527 & 0.001 \\
\hline $\mathrm{CT}$ & $<--$ & SA & 0.315 & 0.315 & 0.052 & 6.036 & 0.001 \\
\hline $\mathrm{CT}$ & $<--$ & PP & 0.128 & 0.128 & 0.053 & 2.442 & 0.015 \\
\hline $\mathrm{CT}$ & $<--$ & Fam & -0.003 & -0.003 & 0.060 & -.055 & $\mathrm{~ns}$ \\
\hline $\mathrm{CT}$ & $<--$ & IQ & 0.032 & 0.059 & 0.180 & .326 & $\mathrm{~ns}$ \\
\hline $\mathrm{CT}$ & $<--$ & PEOU & 0.204 & 0.206 & 0.050 & 4.121 & 0.001 \\
\hline $\mathrm{CT}$ & $<--$ & $\mathrm{BE}$ & 0.103 & 0.104 & 0.068 & 1.534 & $\mathrm{~ns}$ \\
\hline $\mathrm{CT}$ & $<--$ & DT & 0.352 & 0.338 & 0.053 & 6.406 & 0.001 \\
\hline $\mathrm{CT}$ & $<--$ & SV & -0.030 & -0.035 & 0.062 & -.565 & $\mathrm{~ns}$ \\
\hline $\mathrm{CT}$ & $<--$ & $\mathrm{RV}$ & 0.397 & 0.455 & 0.069 & 6.557 & 0.001 \\
\hline $\mathrm{CT}$ & $<--$ & Cus & 0.010 & 0.011 & 0.056 & .193 & $\mathrm{~ns}$ \\
\hline W1 & $<--$ & $\mathrm{CT}$ & 0.279 & 0.320 & 0.071 & 4.505 & 0.001 \\
\hline \multicolumn{8}{|c|}{ Correlations } \\
\hline & & & $\begin{array}{c}\text { Standardized } \\
\text { parameter estimate }\end{array}$ & Estimate & & t value & significance \\
\hline $\mathrm{BE}$ & $\langle-->$ & IQ & 0.500 & 0.358 & 0.075 & 4.743 & 0.001 \\
\hline DT & $\langle->$ & $\mathrm{RV}$ & 0.272 & 0.325 & 0.083 & 3.925 & 0.001 \\
\hline $\mathrm{SA}$ & $\langle--\rangle$ & $\mathrm{RV}$ & 0.184 & 0.212 & 0.077 & 2.747 & 0.01 \\
\hline $\mathrm{PP}$ & $\langle-->$ & $\mathrm{RV}$ & 0.218 & 0.250 & 0.076 & 3.274 & 0.001 \\
\hline TPA & $\langle--\rangle$ & $\mathrm{RV}$ & 0.151 & 0.187 & 0.077 & 2.419 & 0.05 \\
\hline $\mathrm{PP}$ & $\langle--\rangle$ & DT & 0.239 & 0.327 & 0.089 & 3.677 & 0.001 \\
\hline $\mathrm{PP}$ & $\langle--\rangle$ & $\mathrm{Cus}$ & 0.246 & 0.301 & 0.083 & 3.644 & 0.001 \\
\hline
\end{tabular}

In addition to the base model, there are seven interrelations between the exogenous variables that appeared to be significant. The highest correlation is between information quality and brand equity $(\beta=0.5)$, however none of them have a significant effect by itself. The reputation of the vendor is related to a number of other indicants: disposition to trust $(\beta=0.27)$, perceived privacy $(\beta=0.22)$, structural 
assurance $(\beta=0.18)$ and third party assurance $(\beta=0.15)$. The perceived privacy is related to disposition to trust $(\beta=0.24)$ and customization $(\beta=0.25)$ as well as the above mentioned the reputation of the vendor. Whereas $67 \%$ of the variance is accounted for by all independent variables, consumer trust only explains $7.7 \%$ in the 'willingness to buy' construct.

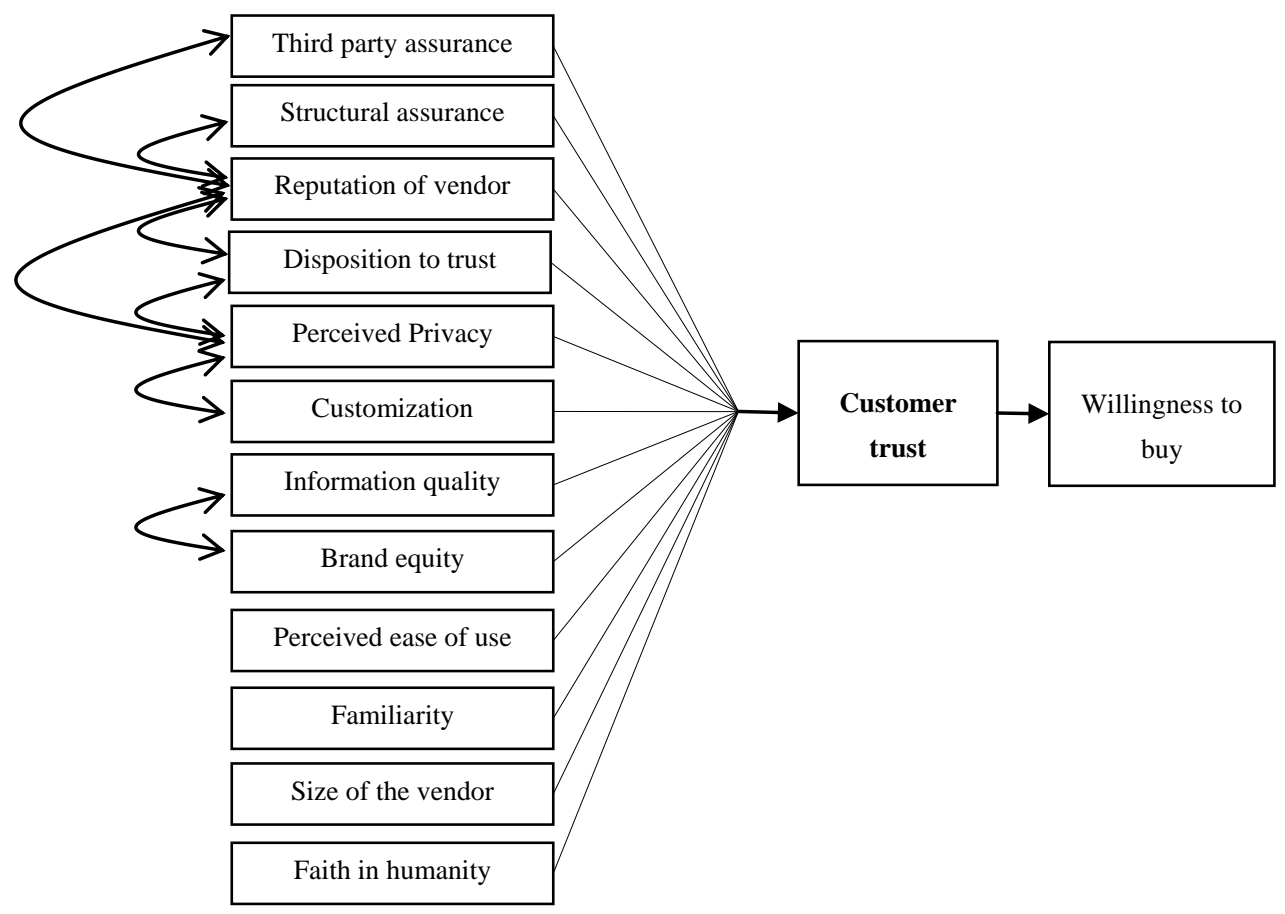

Figure 2 Path Diagram

\section{DISCUSSION}

Trust is considered an important factor in marketing (Young and Wilkinson, 1989), and recent studies have shown that consumer trust plays an important role in explaining the willingness of the consumer to interact with the vendor in technology-mediated service environments (Quelch and Klein, 1996; Gefen, 2000). Our study showed the significant impact of the antecedents on consumer trust, which account for $67 \%$ of the variation in consumer trust. In our study, the reputation of the vendor, disposition to trust and structural assurance have the highest impact on consumer trust, followed by perceived ease of use, third party assurance and perceived privacy; the remaining five factors are non-significant in influencing consumer trust. The fact that consumers considered reputation as the most important factor shows that companies with good reputation also have high credibility in the eyes of the consumer, which reduces the perceived risk and uncertainty towards the company (Doney and 
Cannon, 1997). Reputation can be important during the initial stages of the relationship between company and consumer, when the consumer has no direct experience with the mobile vendor (Koufaris and Hampton-Sosa, 2004).

The other two factors of calculative based trust - size of the vendor and customization - do not seem to significantly impact consumer trust. That is, in wireless media, size does not have a positive effect, and participants do not perceive that the offerings are customized to their needs. Both of these could be very good news to managers, since it allows small companies to be successful in the wireless environment through excellent word-of-mouth activity without being engaged in the resource- and interaction-intense activities that customization would require (Koufaris and Hampton-Sosa, 2004).

Lewicki \& Bunker (1995) claim that the more knowledge the consumer can get, the more trustworthy the vendor is perceived to be. However, this research contradicts them Perceived ease of use is the only factor from knowledge-based trust that has an influence on consumer trust (Yoon, 2002; Sultan et al., 2002). Familiarity (Bhattacherjee, 2002), brand equity and information quality do not have a significant impact on trust. However, the latter two are strongly interrelated to each other. This might mean that mobile devices are not capable of providing sufficient information to the consumer, and most of the consumers may already know what they want, how to get it, and are familiar with the vendor, so they would not rely on the information to judge the trustworthiness of the vendor. Simply put, if you are not known by the consumer through other (traditional) channels, then it is likely that you will not be trusted through the mobile service channel. Strategically, this means that companies have to provide information (knowledge/familiarity) to consumers through other channels, whereas the mobile service channel is more likely to be used for implementation of habitual activities or entertainment related activities.

With regard to the interaction between the independent variables, we can see two major groups: the first is between brand equity and information quality with the strongest correlation, and the second between reputation and disposition to trust, perceived privacy, structural assurance and third party assurance. These findings also indicate that reputation is a very significant antecedent, and it also has a very strong carry-over effect. In this interplay, either the company's reputation - which is gained through other channels - or the customer's disposition can encourage trust. However, three out of 4 components relating to reputation are technology related (institutional), and only one of them (disposition to trust) is related to the characteristics of the consumer. Finally, perceived privacy and willingness to trust are related, as are 
perceived privacy and customization, which implies that both willingness to trust and customization can increase the consumers' perception of privacy.

\section{LIMITATIONS AND FUTURE RESEARCH}

In summary, we have analyzed the impact of individual antecedents on consumer trust and its impact on willingness to purchase. Our model successfully identified the impact of individual factors and their interactions on consumer trust. This study also implies that strategies that have been used to build trust in other transaction channels (such as brick and mortar or e-commerce) can also be applied in the mobile service channel, especially since we have remained within the framework of existing literature in related fields. However, the large proportion of rejected hypotheses also urges us to look carefully at future research. Trust, which is a social antecedent in a relationship between two parties, should be perceived differently in the mobile service channel compared to other traditional channels, and new antecedents and strategies might need to be explored.

In sum, the vendor's, reputation, the individual's attitudes and technology are very closely related to each other and to trust. The first and the third antecedents can be acted upon by the company. However, it would be quite difficult to gain information on the individual's disposition to trust, although reputation and perceived privacy will likely shape the individual's disposition to trust. This study has shown that non-technological factors are more important than technological factors in affecting trust, but the two are closely related to each other.

Finally, some factors could have influenced our research and thus pose limitations. The availability of the mobile applications in a particular country and the existing knowledge and/or experience of consumers with them could significantly influence the survey results. Furthermore, our research did not control for the variety of products/services provided by the same vendor, which could affect the perceived risk and trust towards it.

\section{REFERENCES}

Ancarani, F. and Shankar, V. (2003). Symbian: customer interaction through collaboration and competition in a convergent industry. Journal of Interactive Marketing, 17(1), 56-76.

Anckar, B. and D'Incau, D. (2002). Value creation in mobile commerce: findings from a consumer survey. The Journal of Information Technology Theory and Application, 4(1), 43-64. 
Anderson, J. C. and Gerbing, D. W. (1988). Structural equation modeling in practice: a review and recommended two-step approach. Psychological Bulletin, 103(3), 411-423.

Anderson, J. C. and Narus, J. A. (1990). A model of distributor firm and manufacturer firm working partnerships. Journal of Marketing, 54(1), 42-48.

Balasubramanian, S., Peterson, R. A., and Jarvenpaa, S. L. (2002). Exploring the implications of commerce for markets and marketing. Journal of the Academy of Marketing Science, 30(4), 348-361.

Bhattacherjee, A. (2002). Individual trust in online firms: scale development and initial test. Journal of Management Information Systems, 19(1), 211-241.

Browne, M. W. and Cudeck, R. (1993). Alternative ways of assessing model fit. Sociological Methods and Research, 21(2), 230-258.

Butler, J. K. (1991). Toward understanding and measuring conditions of trust: Evolution of a conditions of trust inventory. Journal of Management, 17(3), 643-663.

Byrne, B. M. (2001). Structural equation modeling with Amos: Basic concepts, applications, and programming. New Jersey: Lawrence Erlbaum Associations.

Chellappa, R. K. and Pavlou, P. A. (2002). Perceived information security, financial liability and consumer trust in electronic commerce transactions. Logistics Information Management, 15(5), 358-368.

Chen, S. C. and Dhillon, G. S. (2003). Interpreting dimensions of consumer trust in e-commerce. Information Technology and Management, 4(3), 303-318.

Clarke, I. (2001). Emerging value propositions for m-commerce. Journal of Business Strategies, 18(2), 133-149.

Culnan, M. J. and Armstrong, P. K. (1999). Information privacy concerns, procedural fairness, and impersonal trust: an empirical investigation. Organizational Science, 10(1), 104-115.

Davis, F. D. (1989). Perceived usefulness, perceived ease of use, and user acceptance of information technology. MIS Quarterly, 13(3), 319-340.

Davis, R. A. and Sajtos, L. (2008). Conceptualizing and measuring consumer interactivity. Journal of Advertising Research, 48(3), 1-17.

De Kerckhove, A. (2002). Building brand dialogue with mobile marketing. Young Consumers: Insight and Ideas for Responsible Marketers, 3(4), 37-43.

Doney, P. M. and Cannon, J. P. (1997). An examination of the nature of trust in buyer-seller relationships. Journal of Marketing, 61(2), 35-51. 
Drosses, D., Giaglis, G. M., Lakeakos, G., Kokkinaki, F., and Stavraki, M. G. (2007). Determinants of effective sms advertising: an experimental study. Journal of Interactive Advertising, 7(2), 16-27.

Ferris, M. (2007). Insight on mobile advertising, promotion, and research. Journal of Advertising Research, 47(1), 28-37.

Gao, T., Sultan, F., and Rohm, A. J. (2010). Factors influencing Chinese youth consumers' acceptance of mobile marketing. Journal of Consumer Marketing, 27(7), $574-583$.

Gefen, D. (2000). E-commerce: the role of familiarity and trust. Omega, 28(6), 725-737.

Gefen, D., Karahanna, E., and Straub, D. W. (2003). Trust and TAM in online Shopping: An integrated model. MIS Quarterly, 27(1), 51-90.

Gerstheimer, O. and Lupp, C. (2004). Needs versus technology - the challenge to design third-generation mobile applications. Journal of Business Research, 47(12), 1409-1415.

Hair, J. F., Anderson, R. E., Tatham, R. L., and Black, W. C. (1998). Multivariate data analysis, New York: Macmillan.

Hooley, G. J., Greenley, G. E., Cadogan, J. W., and Fahy, J. (2005). The performance impact of marketing resources. Journal of Business Research, 58(1), 18-27.

Jarvenpaa, S. L., Lang, K. R., Takeda, Y., and Tuunainen, V. K. (2003). Mobile commerce at crossroads. Communication of the ACM, 46(12), 41-44.

Jun, W. J. and Lee, S. (2007). Mobile media use and its impact on consumer attitudes toward mobile advertising. International Journal of Mobile Marketing, 2(1), $50-58$.

Keller, K. L. (1993). Conceptializing, measuring and managing customer-based brand Equity. Journal of Marketing, 57(1), 1-22.

Kimery, K. M. and McCord, M. (2002). Third-Party Assurance: Mapping the Road to Trust in E-Retailing. Journal of Information Technology Theory and Application, 4(2), 63-81.

Komulainen, H., Mainela, Ta“htinen, T. J., and Ulkuniemi, P. (2007). Retailers' different value perceptions of mobile advertising service. International Journal of Service Industry Management, 18(4), 368-393.

Koufaris, M. and Hampton-Sosa, W. (2004). The development of initial trust in an online company by new customers. Information \& Management, 41(3), 377-397. 
Leppäniemi, M. and Karjaluoto, H. (2005). Factors influencing consumers' willingness to accept mobile advertising: A conceptual model. International Journal Mobile Communications, 3(3), 197-213.

Lewicki, R. J. and Bunker, B. B. (1995). Trust in relationships: A model of trust development and decline. In B. B. Bunker and J. Z. Rubin (Eds), Conflict, Cooperation and Justice: A Tribute Volume to Morton Deutsch (pp. 133-173). San Francisco: Jossey-Bass.

Mayer, R. C., Davis, J. H., and Schoorman, F. D. (1995). An integrative model of organizational trust. Academy of Management Review, 20(3), 709-734.

McKnight, D. H. and Chervany, N. L. (2002). What trust means in e-commerce customer relationships: An interdisciplinary conceptual typology. International Journal of Electronic Commerce, 6(2), 35-59.

McKnight, D. H., Cummings, L. L., and Chervany, N. L. (1998). Initial trust formation in new organizational relationships. The Academy of Management Review, 23(3), 473-490.

Merisavo, M., Kajalo, S., Karjaluoto, H., Virtanen, V., Salmenkivi, S., Raulas, M., and Leppäniemi, M. (2007). An empirical study of the drivers of consumer acceptance of mobile advertising. Journal of Interactive Advertising, 7(2), 261-277.

Morgan, R. M. and Hunt, S. D. (1994). The commitment-trust theory of relationship marketing. Journal of Marketing, 58(3), 20-38.

Nunally, J. C. (1978). Psychometric Theory, New York: McGraw-Hill.

Nysveen, H., Pedersen, P. E., and Thorbjørnsen, H. (2005). Intentions to use mobile services: Antecedents and cross-service comparisons. Journal of the Academy of Marketing Science, 33(3), 1-17.

Nysveen, H., Pedersen, P. E., Thorbjørnsen, H., and Berthon, P. (2005). Mobilizing the brand: The effects of mobile services on brand relationships and main channel Use. Journal of Service Research, 7(3), 257-276.

Okazaki, S. (2005). Mobile advertising adoption by multinationals. Internet Research, 15(2), 160-180.

Okazaki, S. (2009). Mobile finds girls' taste: Knorr's new product development. Journal of Interactive Marketing, 9(2), 32-39.

Park, C. H., and Oung-Gul, K. Y. (2003). Identifying key factors affecting consumer purchase behaviour in an online shopping context. International Journal of Retail \& Distribution Management, 31(1), 16-29. 
Pavlou, P. A. (2001). Integrating trust in electronic commerce with the technology acceptance model: Model development and validation. Proceedings of the Seventh Americas Conference on Information Systems, Boston, USA, 2-5.

Quelch, J. A. and Klein, L. R. (1996). The internet and international marketing. Sloan Management Review, 37(3), 60-66.

Ratnasingham, P. and Pavlou, P. A. (2003). Technology trust in internet-based interorganizational electronic commerce. Journal of Electronic Commerce in Organizations, 1(1), 17-41.

Ratsimor, O., Finin T., Joshi, A., and Yesha, Y. (2003). ENcentive. A framework for intelligent marketing in mobile peer-to-peer environments. Proceedings of the fifth International Conference on Electronic Commerce, Pennsylvania, USA, 236-255.

Reyck, D. B. and Degraeve, Z. (2003). Broadcast scheduling for mobile advertising. Operations Research, 51(4), 509-517.

Rotter, J. B. (1971). Generalized expectation for interpersonal trust. American Psychologist, 26(5), 443-452.

Shankar, V., Urban, G. L., and Sultan, F. (2002). Online trust: a stakeholder perspective, concepts, implications, and future directions. Journal of Strategic Information Systems, 11(3), 325-344.

Siau, K. and Shen, Z. (2003). Building customer trust in m-commerce. Communication of the ACM, 46(4), 91-94.

Siau, K., Sheng, H., and Nah, F. (2003). Development of a framework for trust in mobile commerce. Proceedings of the Second Annual Workshop on HCI Research in MIS, Seattle, USA, 85-89.

Soroa-Koury, S. and Yang, K. C. C. (2009). Factors affecting consumers' responses to mobile advertising from a social norm theoretical perspective. Journal of Telematics and Informatics, 27(1), 103-113.

Sultan, F., Urban, G. L., Shankar, V., \& Lakov, Y. B. (2002). Determinants and Role of Trust in E-Buisness: A Large Scale Empirical Study. Sloan Working Paper,MIT.

Tarasewich, P., Nickerson, R. C., and Warkentin, M. (2002). Issues in mobile commerce. Communication of the ACM, 8(3), 41-64.

Taylor, C. R. and Lee, D. (2008). New media: Mobile advertising and marketing. Psychology \& Marketing, 25(8), 711-713. 
Tsang, M. M., Ho, S., and Liang, T. (2007). Consumer attitudes toward mobile advertising: An empirical study. International Journal of Electronic Commerce, $8(3), 65-78$.

Wang, A. (2007). Branding over mobile and internet advertising: The cross-media effect. International Journal of Mobile Marketing, 2(1), 34-42.

Watson, R. T., Pitt, L. F., Berthon, P. R., and Zinkhan, G. M. (2002). U-commerce: Expanding the universe of marketing. Journal of the Academy of Marketing Science, 30(4), 333-347.

Wei, R., Xiaoming, H., and Pan, J. (2010). Examining user behavioral response to SMS ads: Implications for the evolution of the mobile phone as a bona-fide medium. Telematics and Informatics, 27(1), 32-41.

Wrightsman, L. S. (1991). Interpersonal trust and attitudes toward human nature. San Diego: Academic Press.

Yoon, S. (2002). The antecedents and consequences of trust in online purchase decisions. Journal of Interactive Marketing, 16(2), 47-63.

Young, L. C. and Wilkinson, I. F. (1989). The role of trust and co-operation in marketing channels: A preliminary study. European Journal of Marketing, 23(2), 109-122.

Zaheer, A., McEvily, B., and Perrone, V. (1998). Does trust matter? Exploring the effects of interorganizational and interpersonal trust on performance. Organizational Science, 9(2), 141-159.

Zucker, L. G. (1986). Production of trust: Institutional sources of economic structure. In B. M. Staw, \& J. J. Cummings, Research in Organizational behavior (Vol. 8, pp. 53-111). Greenwich: JAIpr. 


\section{APPENDIX}

Appendix 1 Definition of trust

\begin{tabular}{|c|c|c|}
\hline & Author & Trust antecedent \\
\hline \multirow{6}{*}{ 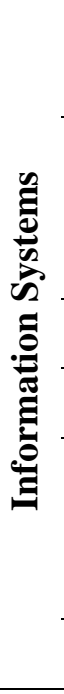 } & $\begin{array}{l}\text { Chellappa \& Pavlou } \\
\text { (2002) }\end{array}$ & Security perception, privacy perception \\
\hline & Gefen et al. (2003) & $\begin{array}{l}\text { Calculative-based, Institution-based structural assurance, } \\
\text { institution-based situational normality, knowledge based familiarity, } \\
\text { perceived ease of use }\end{array}$ \\
\hline & Jarvenpaa et al. (2003) & Perceived size, perceived reputation \\
\hline & Gefen (2000) & Familiarity and disposition to trust \\
\hline & $\begin{array}{l}\text { McKnight \& Chervany } \\
(2002)\end{array}$ & $\begin{array}{l}\text { Disposition to trust (faith in humanity and trusting stance), } \\
\text { Institutional based trust (Structural assurance and situation } \\
\text { normality). }\end{array}$ \\
\hline & Kimery, McCord (2002) & Attention to seal, seal notices \\
\hline \multirow{4}{*}{ 禹 } & Yoon (2002) & $\begin{array}{l}\text { Transaction security, website properties, navigation functionality, } \\
\text { personal variables, website awareness. }\end{array}$ \\
\hline & Doney \& Cannon (1997) & $\begin{array}{l}\text { Characteristics of supplier firm and the supplier firm relationship, } \\
\text { characteristics of the salesperson and salesperson relationship }\end{array}$ \\
\hline & Morgan \& Hunt (1994) & Shared value, communication, opportunistic behaviour \\
\hline & $\begin{array}{l}\text { Anderson \& Naurus } \\
(1990)\end{array}$ & Communication and outcomes given comparison levels \\
\hline \multirow{3}{*}{ 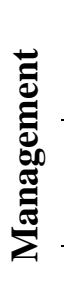 } & McKnight et al. (1998) & $\begin{array}{l}\text { Disposition to trust, institutional-based trust, cognitive processes, } \\
\text { trusting beliefs }\end{array}$ \\
\hline & Butler (1991) & $\begin{array}{l}\text { Availability, competence, consistency, discreetness, fairness, } \\
\text { integrity, loyalty, openness, promise, fulfillment, receptivity. }\end{array}$ \\
\hline & Mayer et al. (1995) & Ability, benevolence and integrity of trustee. Trustor's propensity. \\
\hline
\end{tabular}


Appendix 2 Questionnaire

\section{Characteristics-based Trust}

\begin{tabular}{ll}
\hline \multirow{2}{*}{$\begin{array}{l}\text { Faith in Humanity (Gefen, } \\
2000)\end{array}$} & I generally have faith in humanity. \\
\cline { 2 - 2 } & I feel that people are generally reliable. \\
\cline { 2 - 2 } I generally trust other people, unless they give me a reason not to. \\
\hline \multirow{2}{*}{ Trusting Stance (Gefen, 2000) } & I generally trust other people. \\
\cline { 2 - 2 } Institutional-based Trust & I tend to count upon other people. \\
\hline
\end{tabular}

Generally, I am in favor of buying the advertised brand communicated in messages sent to my mobile phone because there are enough safeguards to make me feel comfortable.

Generally, I am in favor of buying the advertised brand communicated in messages sent to my mobile phone because I feel assured that legal structures adequately protect me from problems.

Structural Assurance (McKnight et al., 1998)
Generally, I am in favor of buying the advertised brand communicated in messages sent to my mobile phone because I feel assured that the technology adequately protects me from problems

Generally, I am in favor of buying the advertised brand communicated in messages sent to my mobile phone because I feel confident that it is safe.

Generally, I am in favor of buying the advertised brand communicated in messages sent to my mobile phone because it is now a safe environment.

...does not disclose consumer private information to unauthorized parties.

...will not share my private information without my consent in the

Perceived Privacy (Pavlou, 2001) future.

...allows me to have control over how the private information I provide will be subsequently used.

...ensures that my privacy will not be compromised during a transaction.

\section{Knowledge based Trust \\ Familiarity (Gefen, 2000)

Information Quality (Koufaris
\& Hampton-Sosa, 2004)
...is playful in the way they communicate. ...provides information that is relevant. ...provides up-to-date information. ...provides information that is consistent. ...provides sufficient information. ...provides information that is easy to understand. 


\section{Appendix 2 Questionnaire (Continued)}

\begin{tabular}{|c|c|}
\hline Knowledge based Trust & \\
\hline \multirow{5}{*}{$\begin{array}{l}\text { Perceived Ease of Use (Gefen } \\
\text { et al., 2003) }\end{array}$} & ...is easy to use \\
\hline & ...is flexible to interact with. \\
\hline & $\begin{array}{l}\text {...enables me to interact with them in a clear and understandable } \\
\text { way. }\end{array}$ \\
\hline & $\begin{array}{l}\text {...is easy to interact with using my mobile phones messaging } \\
\text { services. }\end{array}$ \\
\hline & $\begin{array}{l}\text {...enables me to easily learn how to conduct a transaction using my } \\
\text { mobile phones messaging services. }\end{array}$ \\
\hline \multicolumn{2}{|l|}{ Calculative Based Trust } \\
\hline \multirow{3}{*}{$\begin{array}{l}\text { Size of Vendor (Doney \& } \\
\text { Cannon, 1997) }\end{array}$} & ...is open and receptive to customer needs. \\
\hline & ...is a very large company. \\
\hline & ...is a small player in the market. \\
\hline \multirow{3}{*}{$\begin{array}{l}\text { Reputation of Vendor (Doney } \\
\text { \& Cannon, 1997) }\end{array}$} & ...has a reputation for being honest. \\
\hline & ...is known to be concerned about customers. \\
\hline & ...has a bad reputation in the market. \\
\hline \multirow{4}{*}{$\begin{array}{l}\text { Willingness to Customize } \\
\text { (Koufaris \& Hampton-Sosa, } \\
\text { 2004) }\end{array}$} & ...is willing to customize it's products. \\
\hline & ...is willing to change it's delivery procedures. \\
\hline & ...will respond to my individual needs and desires \\
\hline & ...is willing to provide customized services to it's customers. \\
\hline \multicolumn{2}{|l|}{ Consumer Trust } \\
\hline \multirow{7}{*}{$\begin{array}{l}\text { Consumer Trust } \\
\text { (Bhattacherjee, 2002) }\end{array}$} & $\begin{array}{l}\text {...has the skills and expertise to perform the transaction in an } \\
\text { expected manner. }\end{array}$ \\
\hline & $\begin{array}{l}\text {...has access to the information needed to handle the transaction } \\
\text { appropriately. }\end{array}$ \\
\hline & ...is fair in its conduct of customer transactions. \\
\hline & ...is open and receptive to customer needs. \\
\hline & ...makes good-faith efforts to address most customer concerns. \\
\hline & ...is trustworthy. \\
\hline & ...is fair in its customer service policies. \\
\hline \multicolumn{2}{|l|}{ Consumer Willingness } \\
\hline $\begin{array}{l}\text { Willingness to transact (Gefen } \\
\text { et al., 2003) }\end{array}$ & $\begin{array}{l}\text { Generally, I am in favor of buying the advertised brand through the } \\
\text { mobile device. }\end{array}$ \\
\hline
\end{tabular}


Appendix 3 Sample characteristics

\begin{tabular}{|c|c|c|}
\hline \multicolumn{2}{|c|}{ Category } & Proportion ( 305 usable responses) \\
\hline \multirow{2}{*}{ Gender } & Male & $44.6 \%$ \\
\hline & Female & $55.4 \%$ \\
\hline \multirow{5}{*}{ Age } & $<20$ & $0.02 \%$ \\
\hline & $20-29$ & $42.6 \%$ \\
\hline & $30-39$ & $32.1 \%$ \\
\hline & $40-49$ & $16.7 \%$ \\
\hline & $50+$ & $0.07 \%$ \\
\hline \multirow{2}{*}{ Education } & University level degree & $65.5 \%$ \\
\hline & No degree & $34.5 \%$ \\
\hline \multirow{3}{*}{ Marital Status } & Single & $51.1 \%$ \\
\hline & Married & $46.2 \%$ \\
\hline & Divorced & $2.7 \%$ \\
\hline \multirow{6}{*}{ Ethnicity } & New Zealander & $55.4 \%$ \\
\hline & European & $14.8 \%$ \\
\hline & Asian & $13.8 \%$ \\
\hline & Pacific Islander & $5.2 \%$ \\
\hline & Maori & $0.3 \%$ \\
\hline & Other & $10.2 \%$ \\
\hline \multirow{7}{*}{ Employment } & Full-time & $55.1 \%$ \\
\hline & Part-time & $7.5 \%$ \\
\hline & Self employed & $5.6 \%$ \\
\hline & Unemployed & $1 \%$ \\
\hline & Student & $21.6 \%$ \\
\hline & Homemaker & $6.9 \%$ \\
\hline & Retired & $2.3 \%$ \\
\hline \multirow{8}{*}{ Household annual income (NZ\$)* } & $<30,000$ & $37.8 \%$ \\
\hline & $30,000-39,000$ & $19.1 \%$ \\
\hline & $40,000-49,000$ & $29.8 \%$ \\
\hline & $50,000-59,000$ & $6.3 \%$ \\
\hline & $60,000-69,000$ & $2.3 \%$ \\
\hline & $70,000-79,000$ & $10.0 \%$ \\
\hline & $80,000-89,000$ & $2.3 \%$ \\
\hline & $>90,000$ & $1.7 \%$ \\
\hline \multirow{2}{*}{ Mobile call payment } & Pre & $39.3 \%$ \\
\hline & Post & $60.7 \%$ \\
\hline
\end{tabular}


Appendix 3 Sample characteristics (Continued)

\begin{tabular}{llc}
\hline & Category & Proportion (305 usable responses) \\
\hline & Less than a year & $5.5 \%$ \\
\cline { 2 - 3 } Change Mobile phones & Every year & $14.4 \%$ \\
\cline { 2 - 3 } & Every two years & $30.2 \%$ \\
\cline { 2 - 3 } & Every three years & $39.7 \%$ \\
\cline { 2 - 3 } & More than three years & $10.1 \%$ \\
\hline Mobile phone brand & & \\
\hline Nokia & & $55.7 \%$ \\
\hline Sony Ericsson & & $13.1 \%$ \\
\hline Motorola & $6.9 \%$ \\
\hline Samsung & $5.9 \%$ \\
\hline Alcatel & $3.9 \%$ \\
\hline Sharp & $3.6 \%$ \\
\hline Siemens & $2.9 \%$ \\
\hline Hyundai & $2.3 \%$ \\
\hline Philips & $2.0 \%$ \\
\hline Panasonic & $1.3 \%$ \\
\hline Other & $2.3 \%$ \\
\hline
\end{tabular}


